\title{
Phytoplankton dynamics in permanent and temporary Mediterranean waters: is the game hard to play because of hydrological disturbance?
}

\author{
Luigi Naselli-Flores · Rossella Barone
}

Received: 5 November 2011/Accepted: 24 February 2012/Published online: 15 March 2012

(C) Springer Science+Business Media B.V. 2012

\begin{abstract}
Only few scientific investigations have been carried out, to our knowledge, on phytoplankton in Mediterranean temporary ponds. To test the hypothesis that climate forcing is the main factor affecting dynamics and structure of planktic algae in these peculiar ecosystems, and to assess the importance of human impacts on this basic component of the aquatic biota, phytoplankton structure and dynamics were analysed in two temporary, long lasting (9 months), ponds, and in a permanent one. The three studied water bodies can be classified as mesoeutrophic, which show extended macrophyte beds and are subjected to one or more human impacts, such as eutrophication, fish and plant introduction, and garbage pollution. Phytoplankton samples were collected monthly over two different periods in each
\end{abstract}

Electronic supplementary material The online version of this article (doi:10.1007/s10750-012-1059-3) contains supplementary material, which is available to authorized users.

Guest editors: N. Salmaso, L. Naselli-Flores, L. Cerasino, G. Flaim, M. Tolotti \& J. Padisák / Phytoplankton responses to human impacts at different scales: 16th workshop of the International Association of Phytoplankton Taxonomy and Ecology (IAP)

L. Naselli-Flores $(\bowtie) \cdot R$. Barone

Department of Environmental Biology and Biodiversity, Section of Botany, University of Palermo, Via Archirafi 38, 90123 Palermo, Italy

e-mail: luigi.naselli@unipa.it pond. The identified phytoplankton taxa were grouped in functional coda and non-parametric ordination methods were used to analyse their annual patterns. Results showed a well-defined sequence of coda, which followed a common seasonal pattern in all the studied ponds, when the ordination techniques were applied to a singular water body. This pattern was overlapping in the three studied environments without apparent influence exerted either by the environmental typology (e.g. permanent or temporary) or by human impacts. However, when the analyses were carried out by means of a single matrix containing the coda shared by all the studied environments, they formed a cluster separating the single ponds rather than following common/overlapping seasonal patterns. The results suggest that local effects, particularly the specific composition and richness of phytoplankton assemblages, are as important as climate constraints.

Keywords Mediterranean temporary pond . Functional classification · Coda $\cdot$ Metaphyton · Rare species

\section{Introduction}

Freshwater ponds are small ecosystems distributed worldwide, although they are often neglected. They disproportionately contribute to regional biodiversity because of the high compositional dissimilarity existing among sites (De Meester et al., 2005), which is 
probably linked to their high productivity (NaselliFlores \& Barone, 1994). In addition, in the particular case of temporary ponds, the occurrence of organisms showing specific adaptations to bridge the dry periods results in a very peculiar biota, which is able to deal with the extreme variability of these ecosystems.

In recent years, the scientific community has been showing an increasing interest in these ecosystems, recognizing their complexity (Wilbur, 1997) and their role as model systems (Céréghino et al., 2008); symposia have been regularly organized on issues concerning the conservation and monitoring of temporary and permanent pond biodiversity (Oertli et al., 2005, 2010), and the European Pond Conservation Network (EPCN) was launched in 2004 to promote conservation of ponds and their biodiversity all around Europe. Unfortunately, this increased interest has not been counterbalanced yet by an equal and general interest from the public opinion and/or from local authorities.

Since then, several articles dealing with almost all the biological groups inhabiting temporary and permanents ponds have been published. However, to our knowledge, only a very small number of articles on phytoplankton in temporary ponds are available in the literature (e.g. Robarts et al., 1995; Moyá \& Conforti, 2009; Cunha Pereira et al., 2010). Among these, only Naselli-Flores \& Barone (2002) offered a view on both structural and dynamical aspects of phytoplankton in a Mediterranean temporary pond. This can be partly due to the inherent difficulties in clearly identifying the planktic compartment in these very shallow (maximum depth 1-2 m, but often less than $1 \mathrm{~m}$ ) aquatic ecosystems. Actually, shallowness not only enhances competition among planktic, benthic and metaphytic primary producers, but, depending on hydrodynamic conditions, metaphytic microalgae may enter the plankton and spend there, eventually blooming, a large part of their life history. In the same way, truly planktic algae may settle on bottom sediments and pass a part of their life history out of the plankton. Moreover, the general low interest of the public for this kind of ecosystems makes difficult and not rewarding enough the setting up of the costly and time-consuming analyses aimed at clarifying phytoplankton dynamics and structure.

Among temporary ponds, those occurring in the Mediterranean part of Europe were recognized as being particularly important for their biodiversity, and they were included as a Priority Habitat for the EU under the auspices of the Habitats Directive 92/43/ EEC. More in general, these ecosystems represent in the Mediterranean area the most diffuse typology of natural aquatic environments and, among these, they are presently disappearing at a very fast rate (Cancela da Fonseca et al., 2008). Actually, these ecosystems, which are generally small and shallow, can be recognized as aquatic environments only during the water phase, which, according to Mediterranean climatic features, occurs during the fall/winter rainy season. The extent of the hydroperiod varies from a few weeks to several months depending on the morphological characteristics of these environments, as well as their dry phase. In this last phase, they can hardly be recognized as aquatic ecosystems and appear as land depressions. They are thus severely subjected to human impacts since perfectly suitable to be filled up with litter or wastes and to be appointed for agricultural and urban development (Marrone et al., 2006). In addition, due to their small dimensions, they can greatly suffer pollution by fertilizers, pesticides or garbage, unsustainable water subtraction and/or deepening for conversion into permanent water bodies to fulfil irrigation needs or, paradoxically, to protect aquatic birds. However, the present climate change of Mediterranean basin and the associated overexploitation of underground and surface waters are the factors which mostly threaten temporary ponds, affecting the duration of their hydroperiod and its displacement.

Studies carried out on phytoplankton dynamics and structure in Sicilian temporary and permanent ponds (e.g. Naselli-Flores \& Barone, 2002; Barone et al., 2010) have suggested the existence of a seasonal and compositional coherence in the dynamics and ecological structure of phytoplankton in these two typologies of aquatic ecosystems. This coherence is more pronounced in those temporary ponds characterized by long hydroperiods ( $\geq 9$ months), and it does not appear to be influenced by the breaking in the continuity of the aquatic phase caused by summer drying. This would suggest that temperature and precipitation patterns (and more in general climatic features) greatly contribute to determine the structure and dynamics of phytoplankton assemblages in Mediterranean ponds on a regional scale. Moreover, human impacts (e.g. eutrophication, water overexploitation, introduction of alien species and pollution) are supposed to be harsher on these small ecosystems, 
and thus they should likely affect phytoplankton development causing a change in its seasonal patterns.

The aim of this article, in accordance with the main topic of the 16th Workshop of the International Association for Phytoplankton Ecology and Taxonomy (IAP), is thus to verify the influence of human impacts on the phytoplankton dynamics and structure of these fragile ecosystems, and to test the hypothesis that climate forcing is the main factor affecting the structure and the dynamics of planktic algae in Mediterranean natural ponds. Moreover, we also tried to evaluate how much and in which way it is possible to describe environmental changes by tracking the dynamics of phytoplankton functional groups. To fulfil this task, we compared phytoplankton structure and dynamics recorded, in different years, in one permanent and two temporary Sicilian ponds.

\section{Materials and methods}

\section{Study sites}

Three different ponds were selected in this study: two temporary ['Gorgo di Rebuttone' (GdR) and 'Stagno di Santa Rosalia' (SSR)] and one permanent ['Biviere di Gela' (BdG)]. All the water bodies can be classified as meso-eutrophic, show well-developed macrophyte beds and are subjected to one or more human impacts, such as eutrophication, fish/plants introduction, pollution, disturbance and other stresses.

The GdR is located close to the city of Palermo $\left(38^{\circ} 01^{\prime} 42^{\prime \prime} \mathrm{N} ; 13^{\circ} 19^{\prime} 36^{\prime \prime} \mathrm{E}\right)$ at $720 \mathrm{~m}$ a.s.l., just outside a natural reserve. It is a karstic depression with the bottom covered by clay. Its hydroperiod generally spans from October to July depending on precipitation intensity and duration. It has an elliptical shape with its main axis reaching about $80 \mathrm{~m}$ at maximum holding $\left(z_{\max }: 2 \mathrm{~m}\right)$. The bottom of the pond during the water phase is densely covered by macrophyte beds (Nitella opaca (C. Agardh ex Bruzelius) C. Agardh, Potamogeton natans L. and Zanichellia palustris L.). In spite of its temporary character, local people, from time to time, introduce fish, which are destined to die when the water body dries out. In 2008, Cyprinus carpio L. and Perca fluviatilis L. were observed in the pond.

The SSR is located on a calcareous promontory (Monte Pellegrino) which delimits the northern border of the Gulf of Palermo $\left(38^{\circ} 10^{\prime} 12^{\prime \prime} \mathrm{N} ; 13^{\circ} 21^{\prime} 03^{\prime \prime} \mathrm{E}\right)$, at
$398 \mathrm{~m}$ a.s.l. This is also a karstic depression with the bottom covered by clay. In 1948, the Sicilian Forest Department built on its southern shore a concrete wall $2.5 \mathrm{~m}$ high, to increase the duration of the water phase and use the pond to drink cattle and to irrigate Pinus halepensis Miller and Eucalyptus globulosus Labillardière plantations, which in the present days is surrounding and sheltering the pond. G.E. Hutchinson was inspired to write his seminal article 'Homage to Santa Rosalia or why are there so many kind of animals?' after visiting the pond at the end of 1957 (see Naselli-Flores \& Rossetti, 2010). In 1996, a natural reserve was created to protect the peculiar fauna and flora of the promontory on which lies the pond. As for the Gorgo di Rebuttone, its hydroperiod generally starts in October and lasts until mid-July. It has an elliptical shape with its main axis reaching about $50 \mathrm{~m}$ at maximum holding $\left(z_{\max }: 2 \mathrm{~m}\right)$. In both studied periods, the bottom of the pond during the water phase was densely covered by macrophyte beds (Chara globularis J.L. Thuiller, Spirogyra ellipsospora Transeau and S. cf. lodziensis). In 2010, the introduction of Lemna minuta Kunth, an invasive duckweed from North America, apparently caused the disappearing of most planktic organisms in the pond (Marrone \& Naselli-Flores, 2011).

The BdG is the largest natural coastal lake in Sicily $\left(\approx 1 \mathrm{~km}^{2}\right)$ and one of the few natural wetlands left on the island. It is a brackish water body, with conductivity values ranging between 2.2 and $2.7 \mathrm{mS} \mathrm{cm}^{-1}$, located in SE Sicily $\left(37^{\circ} 01^{\prime} 13^{\prime \prime} \mathrm{N}, 14^{\circ} 20^{\prime} 30^{\prime \prime} \mathrm{E}\right)$, $1.3 \mathrm{~km}$ from the Mediterranean coast and $8 \mathrm{~m}$ a.s.l. In 1987-1988, its maximum length was $2.5 \mathrm{~km}$, maximum depth fluctuated between 6.5 and $7.5 \mathrm{~m}$ and mean depth was less than $3 \mathrm{~m}$. The pond has no surface outflow and no important inflow, being fed during the rainy season by an ephemeral surface stream. In 1988, it has been designated for the List of Wetlands of International Importance and included in the 'Ramsar Act'. In 1997, a Nature Reserve has been created by the Sicilian Region to preserve the several rare and endangered vertebrate species (e.g., amphibians, turtles, and birds) that inhabit the pond. At the beginning of the millennium, it suffered an almost complete drying because of the decreased water availability from the catchment. To preserve this Ramsar site, at the end of 2004, it was suddenly filled up with water coming from a nearby reservoir and depth passed from 1.5 to $5.5 \mathrm{~m}$ in a few days. The 
consequences of these events, which deeply influenced the composition and dynamics of phytoplankton, were analysed in details by Barone et al. (2010).

\section{Phytoplankton and environmental data}

Data collected in two different periods in each water body were selected for this study. Six different datasets were used: GdR was sampled in 2003-2004 and in 2007-2008, SSR in 1998-2000 and in 2008-2009 and BdG in 1987-1988 and 2005-2007. Samples were collected with different frequencies (weekly, biweekly or monthly) in the different water bodies and in the different periods. In the present study they were pooled in monthly data to uniform the six datasets.

Water samples for phytoplankton analysis were collected sub-superficially in all the three water bodies. At the same time, net-plankton samples were taken by towing vertically and/or horizontally a $25-\mu \mathrm{m}$ mesh net. Half of the concentrated samples was fixed in $4 \%$ buffered formaldehyde. Species identification was carried out on living samples using the most up-to date phycological literature. Phytoplankton water samples for counting were immediately preserved in Lugol's iodine solution; cell counting was performed using a Zeiss-Axiovert 100 inverted microscope in accordance with the sedimentation method developed by Utermöhl. Wet weight biomass was calculated from recorded abundance and specific biovolume estimates, based on simple geometric shapes (Hillebrand et al., 1999) and assuming unit specific gravity. Species were pooled into functional groups following the recommendations given by Padisák et al. (2009). For those species not listed in this last quoted article (e.g. Chaetoceros muelleri Lemmerman, brackish water species), attribution to a specific codon was performed according to what specified in Reynolds et al. (2002).

Water samples for nutrients ( $\mathrm{SRP}, \mathrm{N}-\mathrm{NH}_{4}, \mathrm{~N}-\mathrm{NO}_{2}$, and $\mathrm{N}-\mathrm{NO}_{3}$ ) were collected sub-superficially, refrigerated and taken to the laboratory where the analyses were performed according to Tartari \& Mosello (1997). Temperature and conductivity values in the water were recorded using a mutiparametric probe.

\section{Statistical analyses}

The datasets used for statistical analyses consisted of species-specific biovolume estimates of phytoplankton.
Phytoplankton taxa that were present with a relative biovolume greater than $1 \%$ in more than one sample, were included in the ordination analyses. The monthly biovolume values were transformed to reduce the weight of the most abundant taxa. Two different transformation procedures $\left(y_{i}=\log \left(x_{i}+1\right) ; \quad y_{i}=\right.$ $\sqrt[4]{x_{i}}$ ) were used, according to data distribution. In each water body, three matrices were prepared and analysed: one phytoplankton matrix (taxa $\times$ sampling dates) considering the original data (the biomass of the single species), and two additional synthetic matrices after grouping the algae (i) into functional groups and (ii) into algal classes. For both the studied periods, the three matrices were transformed into dissimilarity matrices by computing the Bray-Curtis' dissimilarity index (Podani, 2000) and then ordinated separately in a two-dimension plane, by means of non Metric Multidimensional Scaling (nMDS). Two additional matrices were analysed in the same way. These were prepared using only (i) the functional groups and (ii) the species shared by all the studied environments. In addition, as regards the permanent water body (BdG) only the dataset collected in 1987-1988 was used, and only the 9-month period corresponding to the water phases of the two temporary environments were considered. All the ordinations were performed with the free software PAST (Hammer et al., 2001). To assess the reliability of NMDS graphs, stress value was computed according to Kruskal \& Wish (1978).

\section{Results}

Environmental parameters and phytoplankton biomass

The annual variability of the main environmental parameters in the studied water bodies is shown in Figs. 1 and 2.

As regard the studied temporary ponds, the water phase generally begins in late September/early October and ends in July (Fig. 1). The figure represents a synthesis of the measures carried out in both the studied temporary ponds during all the sampling periods. In this case, the trends followed by the variables are considered much more informative than absolute numerical values (shown in Supplementary material), which may be highly variable depending on the variability of meteorological elements. Strictly 

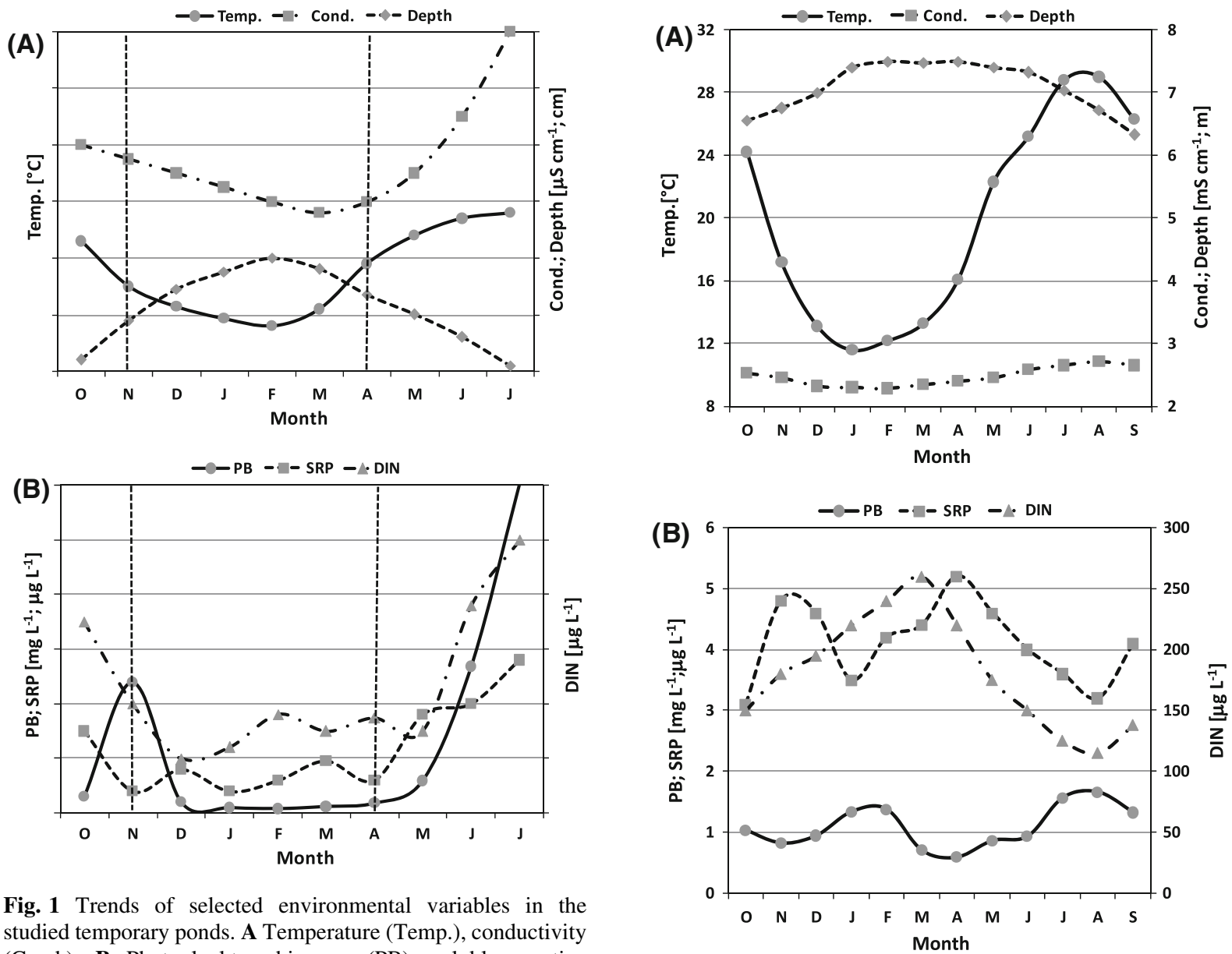

Fig. 1 Trends of selected environmental variables in the studied temporary ponds. A Temperature (Temp.), conductivity (Cond.). B Phytoplankton biomass (PB), soluble reactive phosphorus (SRP) and dissolved inorganic nitrogen (DIN). Vertical dashed lines delimit the most frequent period of occurrence of annual macrophytes

linked to the precipitation regime under the Mediterranean climate, water temperatures and conductivity in the temporary ponds (Fig. 1A) show their minimum values at the end of winter/beginning of spring. The conductivity minimum appears to be delayed and follows that of temperature because of the occurrence of early spring precipitation events and their dilution effects. After this, the rapid spring increase of temperature and the absence of rain enhance evaporation effects and conductivity values again start increasing up to their maximum annual value, which generally precede the drying of the pond. The patterns of precipitation, water temperature and evaporation rates also influence the maximum depth, and thus the minimum temperature generally corresponds to the highest annual precipitation and maximum depth of

Fig. 2 Trends of selected environmental variables in the studied permanent pond during 1987-1988. A Temperature (Temp.), conductivity (Cond.). B Phytoplankton biomass (PB), soluble reactive phosphorus (SRP) and dissolved inorganic nitrogen (DIN)

these temporary water bodies. Deviations from the above described patterns largely depend on annual weather fluctuations, which are typical of Mediterranean climate. As an example, the water phase in $\mathrm{GdR}$ was much more prolonged in 2007-2008 because of the intense winter-spring precipitation in both the sampled years. This allowed the pond to maintain some water in the deepest depressions of its bottom throughout summer 2007 and 2008.

Phytoplankton total biomass $(\mathrm{PB})$ in the temporary ponds showed a bimodal trend (Fig. 1B) with one peak $\left(>20 \mathrm{mg} \mathrm{l}^{-1}\right.$ ) a few weeks after the beginning of the water phase and a second one which started in spring and reached its maximum $\left(>60 \mathrm{mg} \mathrm{l}^{-1}\right.$ ) just before the complete drying of the water bodies. The period 
between these two peaks is always characterized by very low values of phytoplankton biomass $(1<\mathrm{PB}$ $<2 \mathrm{mg} \mathrm{l}^{-1}$ ).

Soluble reactive phosphorus (SRP) and dissolved inorganic nitrogen (DIN) in the temporary ponds appear to be abundant and immediately available for phytoplankton growth since the beginning of the water phase (Fig. 1B). In both the studied environments and in all the studied periods, at the beginning of the water phase, SRP values are above $10 \mu \mathrm{g} \mathrm{l}^{-1}$ and DIN values are above $300 \mu \mathrm{g}^{-1}$. Then, they rapidly decrease and fluctuate around lower values during winter and early spring. A second increase occurs in May, immediately followed by the second phytoplankton peak.

The trends of temperature, conductivity and depth in the permanent water body (Fig. 2A) are similar to those shown in temporary ponds, once the temporal sequence is ordered from October to September. Only the data recorded during 1987-1988 are shown in the figure because this period was considered more comparable than the period 2005-2007 when, to ward off the complete drying of the pond, management procedures were applied, which, being aimed at a sudden increase of the water level, deeply altered the phytoplankton composition and dynamics (for more details see Barone et al., 2010).

Phytoplankton biomass values are lower than in temporary ponds $\left(<2 \mathrm{mg}^{-1}\right)$ with one peak in February and a second one in August (Fig. 2B). These lower values recorded in the permanent pond reflect the minor availability of dissolved nutrients for phytoplankton growth. As regards DIN, the values showed a unimodal trend with one peak in March $\left(260 \mu \mathrm{g}^{-1}\right)$; a bimodal trend, out of phase with phytoplankton biomass, is followed by SRP, with one peak in November $\left(4.8 \mu \mathrm{g}^{-1}\right)$ and a second one in May $\left(5.2 \mu \mathrm{g} \mathrm{l}^{-1}\right)$.

\section{Phytoplankton composition}

A very high species richness characterized the microalgal flora found in the plankton of the studied ponds and more than 450 taxa were identified. Phytoplankton class composition in all the studied ponds showed a clear seasonal pattern with cryptophytes and/or diatoms dominating in winter and chlorophytes in early spring. These were followed by an assemblage rich in euglenophytes, often accompanied by dinoflagellates, which co-dominated the late-spring/summer assemblages.
This pattern, although characterized by several different species, was quite regular in all the studied periods except in the permanent pond (BdG) in 2005-2007. In this period a quite different dynamics and structure of phytoplankton assemblages was detected: the haptophyte Prymnesium parvum Carter replaced cryptophytes and diatoms in winter and chlorophytes extended their period of dominance or subdominance throughout all the investigated period, with peaks of biomass in late summer. Moreover, cyanobacteria, which were virtually absent in 1987-1988, bloomed in early summer with relative biomass values ranging between 40 and $60 \%$ of the total.

In temporary ponds, among typical and common phytoplankton species (e.g. Pediastrum spp., Coelastrum spp., Botryococcus braunii Kützing, Mucidosphaerium pulchellum (H.C. Wood) C. Bock, Proschold \& Krienitz, Staurastrum spp., Ceratium hirundinella (O.F. Müller) Dujardin, Peridinium spp., Plagioselmis nannoplanctica (Skuja) Novarino, Lucas et Morral, Cryptomonas spp.), the occasional presence of several metaphytic species was very often recorded. These species are not truly planktic but they can significantly contribute to the total biomass of phytoplankton. Their appearance in the plankton of the studied temporary ponds was generally punctual (e.g. occurring in a single sample) and linked to resuspension events. All these not-truly planktic species were grouped in the MP codon.

Among the most abundant metaphytic organisms exclusively found in the temporary ponds, Glaucocystis nostochinearum Itzigsohn, a member of Glaucocystophyta, reached, in April 2007, the 16\% of total phytoplankton in GdR. In the same pond another member of this phylum, Cyanophora paradoxa Koršikov, was found in July 2004 with a much lower relative biomass value (2\%). The volvocalean Rusalka fusiformis (Matv.) Nakada showed a relative contribution to total biomass higher than $20 \%$ in early spring 2008, whereas several other species (e.g. Diacanthos belenophorus Koršikov, Vitreochlamys fluviatilis (Pascher) Batko, Treubaria triappendiculata C. Bernard, Chlorogibba allorgei Bourrelly \& Manguin, Polyedriopsis spinulosa (Schmidle) Schmidle) showed a contribution ranging between 2 and 3\%. In SSR, the 'metaphytic contingent' was formed, among others, by Keratococcus bicaudatus (A. Braun ex Rabenhorst) J.B. Petersen, Centritractus belenophorus Lemmermann, Spermatozopsis exsultans Koršikov. Even in 
this case, these species gave a small contribution to total biomass.

Phytoplankton ordination and occurrence of functional groups

In all the studied ponds and in all the periods, matrices formed by phytoplankton single species did not result in clear ordinations. Conversely, the configurations of the phytoplankton samples pooled into selected functional groups and obtained by NMDS resulted in a temporal arrangement in each pond for both the studied periods (Figs. 3, 4, 5). The stress values of these NMDS configurations are always lower than 0.20. Ordination obtained using the phylogenetic classes is superimposed to the one obtained using the functional groups. The latter contemporary allows a higher resolution than what was provided by classes and offer a higher readability than the single species.

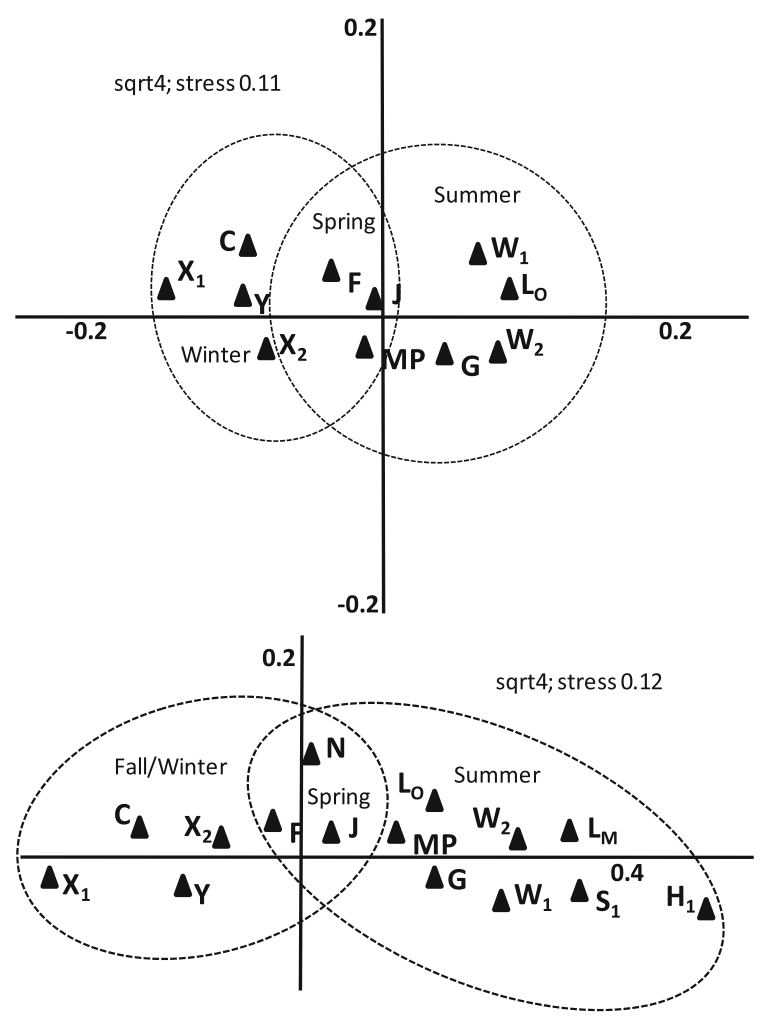

Fig. 3 Gorgo di Rebuttone (GdR). Non metric multidimensional scaling plots of the phytoplankton pooled into functional groups in the two studied periods. Above 2003-2004; below 2007-2008
Functional groups clearly reveal the temporal ordination of the samples and are divided into two main groups, which may be identified with summer and winter seasons, in all the studied periods.

Phytoplankton species of the three ponds were allocated in 20 coda. However, only eight coda (W1, $\mathbf{W 2}, \mathbf{X 1}, \mathbf{X 2}, \mathbf{J}, \mathbf{F}, \mathbf{Y}$ and MP) were present in all the studied environments but in the permanent pond in the period 2005-2007, when no representatives of the coda W1 (not bottom-dwelling euglenoids), W2 (bottom-dwelling euglenoids) and MP (meroplankton) were found.

In GdR, 11 functional groups were present in 2003-2004 and 15 in 2007-2008 (Fig. 3). The higher number of functional groups in 2007-2008 was mainly due to the summer appearance of the coda S1, H1 and $\mathbf{L}_{\mathbf{M}}$. All these coda are formed by cyanobacteria: codon S1 groups shade-adapted cyanobacteria
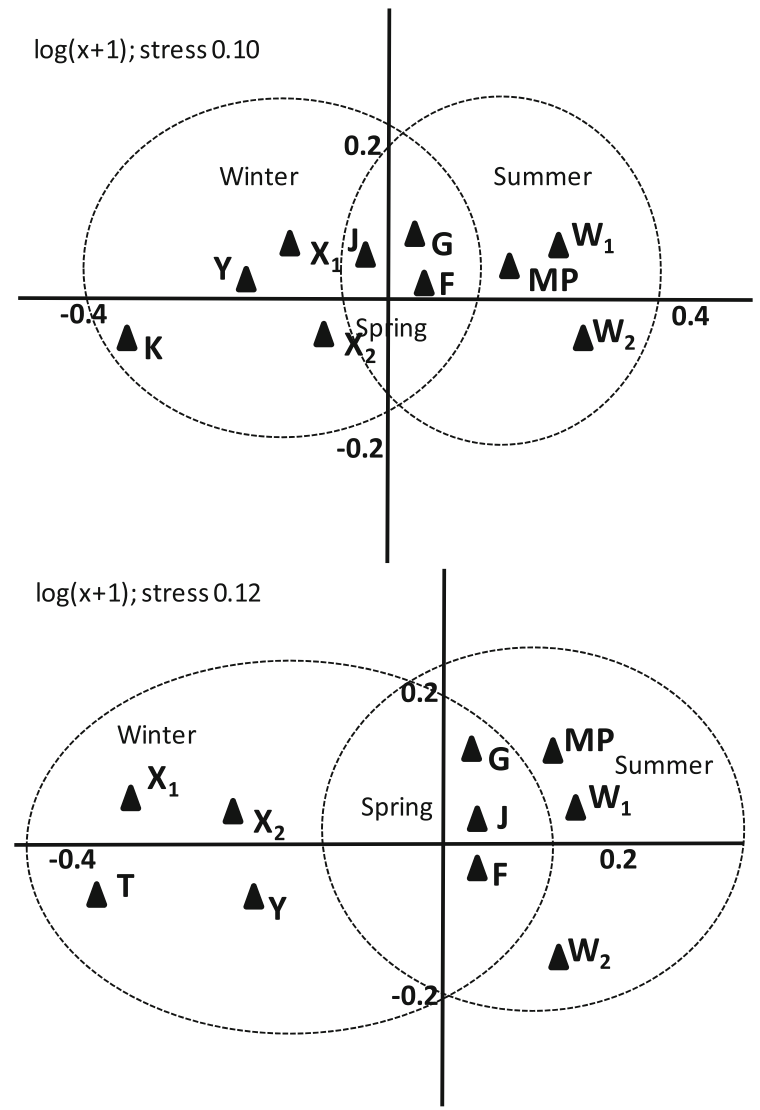

Fig. 4 Stagno di Santa Rosalia (SSR). Non metric multidimensional scaling plots of the phytoplankton pooled into functional groups in the two studied periods. Above 1998-2000; below 2008-2009 


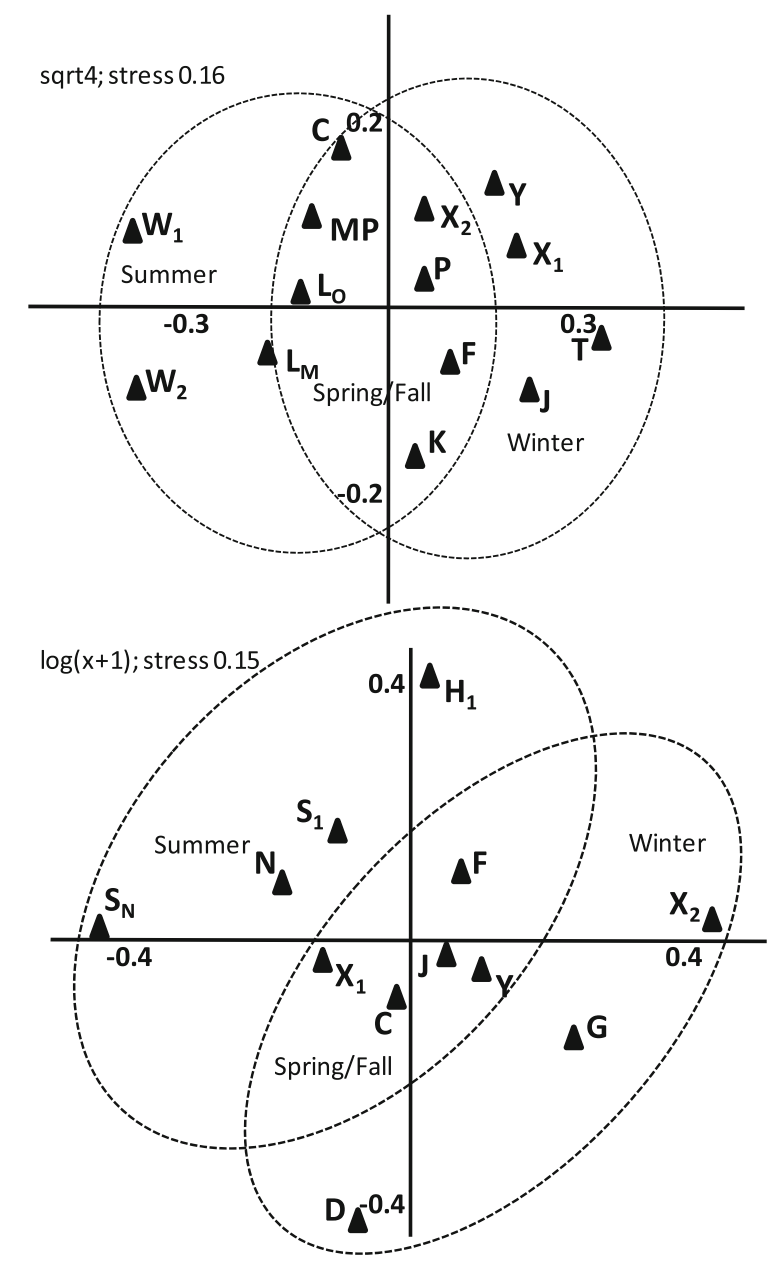

Fig. 5 Biviere di Gela (BdG). Non metric multidimensional scaling plots of the phytoplankton pooled into functional groups in the two studied periods. Above 1987-1988; below 2005-2007

(Limnothrix sp., Planktothrix sp.); codon H1 collects gas-vacuolated nostocaleans [Dolichospermum planctonicum (Brunnth.) Wacklin, L.Hoffm. \& Komárek and Anabaenopsis elenkinii V.V. Miller], and codon $\mathbf{L}_{\mathbf{M}}$ is formed by Microcystis spp. co-occurring with $C$. hirundinella (O.F. Müller) Schrank. These coda were observed to co-occur with codon W1 (Euglena spp., Lepocinclis ovum (Ehrenberg) Minkevich, Phacus spp.) and W2 [Trachelomonas spp., Strombomonas acuminata (Schmarda) Deflandre]. In addition, codon N [Staurastrum crenulatum (Nägeli) Delponte], typical of continuous or semi-continuous mixed layer of 2-3 $\mathrm{m}$ in thickness, dominated late-winter/earlyspring assemblage in 2008 accompanied by members of codon J (Pediastrum spp., Coelastrum spp.,
Scenedesmus spp., Desmodesmus spp.) and $\mathbf{F}$ (Oocystis spp., Kirchneriella spp., B. braunii Kützing). Coda X1 (Monoraphidium spp., Ankistrodesmus spp.), X2 (Plagioselmis sp., Chlamydomonas spp.), and $\mathbf{Y}$ (large cryptomonads, small dinoflagellates) characterized the fall/winter period in 2007-2008.

In SSR, 10 coda were identified in 1998-1999 as well as in 2008-2009 (Fig. 4). Codon K (Aphanotece sp., Synechococcus sp.) characterizing winter in 1998-1999 is replaced by codon T (Planctonema lauterbornii Schmidle, Mougeotia sp.) in 2008-2009. No other major changes can be noted by comparing the ordinations in the different studied periods but the appearance of the xanthophyceans Goniochloris mutica (A. Braun) Fott and G. smithii (Bourrelly) Fott (codon $\mathbf{J}$ ) which bloomed at the beginning of March 2009 , reaching in one single sample a relative value above $60 \%$ of total biomass.

In BdG, by comparing the two nMDS ordinations, it is possible to see that a lower number of coda characterized the second, more recent period, and only five of these coda $\left(\mathbf{C}, \mathbf{F}, \mathbf{J}, \mathbf{X}_{\mathbf{1}}, \mathbf{Y}\right)$ were present in both periods (Fig. 5). In some cases, the species included in the group were not the same: codon $\mathbf{C}$, mainly formed by $C$. muelleri Lemmermann in 1987-1988, contained Cyclotella meneghiniana Kützing in 2005-2007, and codon $\mathbf{J}$ was much richer in species in 2005-2007 than in 1987-1988. Moreover, the seasonal occurrence of these shared groups showed a shift from winter, in 1987-1988, to summer in 2005-2007. New coda, not present in the pond in 1987-1988 appeared in 2005-2007 replacing euglenoids, which disappeared in the pond. These are formed by the cyanobacteria Cylindrospermopsis raciborskii (Wolosz.) Seena. \& Subbar. $\left(\mathbf{S}_{\mathbf{N}}\right)$, Aphanizomenon ovalisporum Forti (H1) and Pseudoanabaena limnetica (Lemmermann) Komárek (S1).

The NMDS plot showing the ordination of the functional groups shared by all the studied ponds in all the investigated periods (with the exclusion of the permanent pond in the period 2005-2007) is shown in Fig. 6. Only eight coda (W1, W2, J, F, X1, X2, Y and MP) were used in this analysis. These may be regarded as the basic pool of ecological strategies exhibited by phytoplankton assemblages in Mediterranean ponds. No seasonal patterns resulted from the ordination. Conversely, the coda of each pond grouped together and formed three clearly separated clusters. 


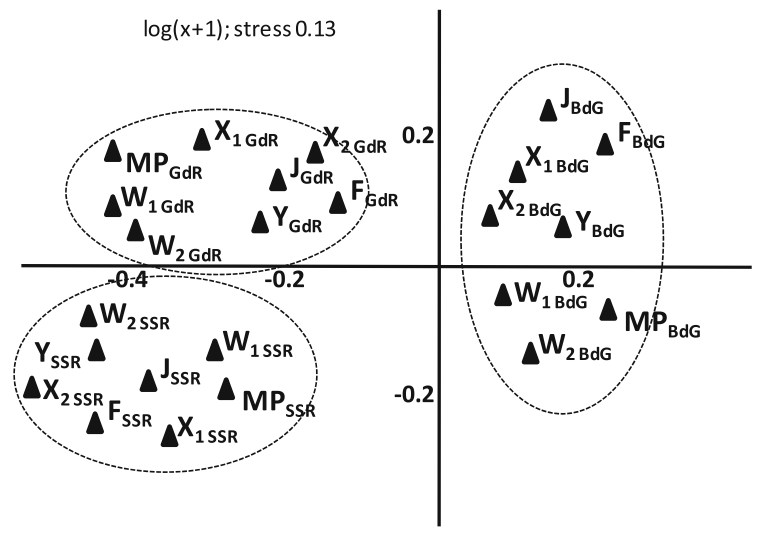

Fig. 6 Non metric multidimensional scaling plot of the eight phytoplankton functional groups shared by the studied ponds. BdG: Biviere di Gela; GdR: Gorgo di Rebuttone; SSR: Stagno di Santa Rosalia

\section{Discussion}

Environmental parameters and phytoplankton biomass

Mesotrophic and eutrophic shallow lakes and ponds exhibit alternative stable states either dominated by macrophytes or by phytoplankton (Scheffer, 1998). Macrophytes play a crucial role in creating and maintaining a clear water phase in these ecosystems by several mechanisms (e.g. Van Donk \& Van de Bund, 2002). Among these, one of the most studied although not definitively demonstrated (Gross et al., 2007), is allelopathy. A major ecosystem stress is thus necessary to move an aquatic ecosystem from a clear water, macrophyte-dominated state to a turbid, phytoplankton-dominated alternative one. This was the case of the permanent pond $\mathrm{BdG}$ which, in the early years of this century, was almost disappearing because of a reduction of its water income (Barone et al., 2010). A disruption of the wide littoral zone occurred with the consequent loss of its perennial macrophytes and an increased nutrient availability for phytoplankton. Thus, the structure and dynamics of phytoplankton has shown deep changes and a shift from a clear state (1987-1988) to a turbid one (2005-2007) has taken place, as predicted by Sheffer's theory on the alternative stable states (Scheffer, 1998).

From the results as above achieved, it appears that, In contrast to what happen to permanent shallow lakes and ponds, temporary ponds pass physiologically from a turbid, phytoplankton dominated state to a clear, macrophyte dominated one and vice versa. The reasons for this peculiar behaviour lie in the intrinsic functioning features of these environments: temporary ponds are natural bodies of water which experience a recurrent dry phase; this is predictable both in its time of onset and duration (Williams, 2006). The cyclical nature of the dry phase and its predictability thus allows temporary water species to be adapted to water loss. Macrophytes inhabiting Mediterranean temporary ponds are not perennial, and are represented by annual plants (including Charophyta), which quickly germinate after the first rains in early autumn and grow throughout winter until reproduction in late winter or spring; other species germinate at the end of winter when water recedes and reproduce faster (Grillas et al., 2009). Macrophytes in the studied temporary ponds completed their life-cycles by mid-April and naturally disappeared afterwards. Before their germination and after the end of their annual cycle, phytoplankton have thus access to unlimited amounts of resources, which allow them to attain high biomass values.

In the studied temporary ponds amount of available nutrients (both DIN and SRP) higher than those occurring in the permanent one were recorded. This is also linked to the temporary nature of these environments. Mozley (1944), in one of the first articles dealing with temporary ponds, suggested that the seasonally alternating summer dry phase and winter water phase mutually feed each other. Terrestrial and aquatic communities are actually linked by a reciprocal legacy of organic matter which is seasonally left from one community to the following. The mineralization of this organic matter largely depends on the establishment of a well-structured and efficient microbial community, which could sustain a quick recycling of inorganic nutrients readily available to primary producers (Battle \& Mihuc, 2000).

As shown by Fazi et al. (2008), in Mediterranean temporary waters the aquatic microbial community is fully functioning 9-28 $\mathrm{h}$ after a pond passes from the dry to the wet phase. Although the time needed to reactivate the aquatic microbial food web after the arrival of new water largely depends on the duration and intensity of the precedent dry phase (Amalfitano et al., 2008), this is generally quick enough to supply high amount of inorganic nitrogen and phosphorus to phytoplankton, allowing this primary producers to 
peak in a few days, well before the establishment of the plant community. Later on, plants (and epiphytic algae) start their life-cycle and monopolize the resources keeping phytoplankton biomass at low values. A similar trend of phytoplankton biomass was described by Ribeiro Rodrigues et al. (2011) who studied the plankton dynamics of a subtropical temporary wetland and by Cunha Pereira et al. (2010) who investigated primary production in turloughs (Irish karstic temporary ponds).

When water starts receding in spring, plants have generally completed their cycle and their organic matter enters the microbial food chain. Available DIN and SRP tend to increase again in this period probably sustained by internal recycling and phytoplankton show its second biomass peak. This second, more intense, peak of biomass is also enhanced by the water reduction, which concentrates phytoplankton cells, and lasts up the complete desiccation of the water body.

\section{Phytoplankton composition}

The high number of species which characterizes the phytoplankton microflora of the studied ponds, and especially those of temporary ponds, has to be sought in the environmental features of these ecosystems. The temporary ponds selected in this study host a dense plant community during their water phase and the bottom was almost completely covered by macrophyte from mid-November to mid-April in the studied periods. During the macrophyte-dominated periods, planktic species were found to coexist with metaphytic microalgae and with microphytobenthos, since in these ecosystems, a typical pelagic zone do not exist during the plant growing period. This mixture of microalgae was more evident in the temporary ponds than in the permanent one and can be related to the higher macrophyte coverage of these environments. According to Borics et al. (2003), in those environments where aquatic macroflora is diverse and morphologically structured, many microhabitats may develop and a richer microflora generally occurs. In addition, as shown by Krasznai et al. (2010), the composition of phytoplankton assemblages in ponds is exclusively dependent on macrophyte coverage; these authors, studying 64 Hungarian ponds characterized by different macrophyte coverages, found that when the coverage was higher than $40 \%$, the occurrence of cyanobacteria (coda S1, H1) was unlikely, whereas euglenoids and metaphytic volvocalean species developed frequently. Accordingly, in the present study cyanobacteria belonging to S1, H1 appeared in the temporary GdR in summer 2007-2008, when an unusually prolonged water phase occurred after the disappearing of the annual plant community. Also in the permanent pond $\mathrm{BdG}$, the suppression of the macrophyte coverage promoted the appearance of bloom-forming cyanobacteria belonging to the coda S1, $\mathbf{H 1}$ and $\mathbf{S}_{\mathbf{N}}$. Since the macrophytes of the permanent pond were perennial species, their removal caused a permanent shift from a macrophyte-dominated environment with clear waters to a phytoplankton-dominated, turbid environment.

More in general, a highly diversified microflora formed by metaphytic microalgae and euplanktic green algae was commonly found in winter and spring. Euglenoids were dominating the pond microflora since mid-April to the end of the water phase when they were generally found to attain high biomass values.

Phytoplankton ordination and occurrence of functional groups

Mediterranean area is characterized by periodical oscillations in precipitation and temperature which may deeply affect the functioning of the aquatic ecosystems subjected to its peculiar climate (NaselliFlores, 2003; Naselli-Flores \& Barone, 2005; NaselliFlores et al., 2007). The interannual variability in the total amount and monthly distribution of precipitation causes significant variations not only at the length of the Mediterranean temporary ponds' hydroperiod but also at the start of their flooding period (Dimitriou et al., 2009). Naselli-Flores \& Barone (2002) showed that these two variables may strongly condition the dynamics of phytoplankton assemblages inhabiting temporary ponds.

In spite of the strong influence exerted by meteorological elements, all the studied ponds exhibited a temporal gradient which was marked by a clear sequential appearance of functional groups. In particular, the seasonal sequence of coda X1/Y $\rightarrow$ X2 $\rightarrow$ $\mathbf{F} \rightarrow \mathbf{J} \rightarrow\left(\mathbf{L}_{\mathbf{O}}\right) \mathbf{W} \mathbf{1} / \mathbf{W} 2$, which appeared proceeding from the flooding to the drying phase, strongly characterizes the seasonal succession of phytoplankton in Mediterranean temporary ponds. These coda, 
along with the MP one, were commonly found in all the studied ponds. Since functional groups closely reflect the adaptive strategies of phytoplankton to environmental constraints (Reynolds et al., 2002), this recurrently observed sequence must have an ecological meaning. In fact, the codon $\mathbf{X} \mathbf{1}$ collects small, fastgrowing algae inhabiting turbid, nutrient-rich environments. They well cope with the initial flooding phase when a high nutrient availability and the absence of zooplankton may favour them in the formation of biomass bulks. Also members of the codon $\mathbf{Y}$, which collects mixotrophic cryptomonads, are favoured by the absence of zooplankton and by the abundant organic matter typical of the flooding phase. Codon X2 mainly develops in clearer meso-eutrophic water bodies. This is the condition which follows the flooding phase, when annual plants start growing, and water transparency increases. As the depth of the pond increases, codon $\mathbf{F}$ representatives become more frequent. This functional group is described as typically found in clear epilimnia. Later on, when the plants start disappearing, codon $\mathbf{J}$, members of which are abundant in shallow, nutrient-rich environments, follows with high biomass values. The drying phase is characterized by the very diversified assemblage mainly formed by euglenoids (W1 and W2) often accompanied by dinoflagellates $\left(\mathbf{L}_{\mathbf{O}}\right)$. They generally persist up to the complete desiccation of the pond, often forming a green thin layer on the wet soil. Moreover, due to their photoauxotrophic metabolic needs, they start becoming abundant when the life cycle of annual plants is completed and the availability of organic matter in the water is higher.

The sequence of these phytoplankton functional groups thus summarizes and represents the seasonal progression of ecological events, which characterizes the water phase of the Mediterranean temporary ponds. In addition, it may be argued that these groups collect species which are better adapted to survive the dry phase. Other groups of microalgae likely colonize these water bodies from surrounding permanent environments (Chrisostomou et al., 2009) and their success can be variable in different years. Moreover, several taxa belonging to the coda $\mathbf{X 1}, \mathbf{X 2}$ and $\mathbf{J}$ are commonly found among airborne autotrophic eukaryotes (Genitsaris et al., 2011), thus suggesting that members of these coda are the most probable recolonizers of ponds after the dry phase. A confirmation to this hypothesis comes from the minor number of coda, and their lower variability, recorded in the more sheltered SSR. This pond is actually surrounded by woodlands, conversely to GdR, which lays in a grassland landscape and which showed a higher variability in the number of coda recorded in the two studied periods.

It can be argued that the dry phase act as a 'resetting" phase of the temporary systems, which can re-open the competitive arena to new potential colonizers (Foissner, 2006), and eventually counteract some human impacts such as garbage pollution and the introduction of fish and plants. Actually, the survivorship of these alien elements is promptly stopped by the annual desiccation of the pond. This resetting phase largely smoothens the harshness of human impacts but those which interfere with the hydrological cycle and are depending on climate change of the Mediterranean area.

In permanent ponds, the resetting phase is absent and this absence likely decreases the resilience of the systems. Actually, the above quoted sequence of coda was also present in the permanent pond in 1987-1988, during the clear water, macrophyte-dominated period. Since the macrophyte species in permanent ponds are perennial species, they could not cope with the drying of the pond, which occurred at the beginning of the century (Barone et al., 2010). The permanent disappearing of the macrophyte in the pond allowed phytoplankton to become dominant and promoted a permanent shift towards an alternative stable state. The adaptive strategies to survive the dry phase performed by the inhabitants of temporary waters thus contribute to make these environments more resilient than permanent ones.

No temporal gradients appeared when the eight shared functional groups were pooled in a single matrix and ordinate by nMDS. This was in conflict with our initial hypothesis of a regional coherence in phytoplankton dynamics, which is driven by climatic features. If this hypothesis had been confirmed, the same coda should group together depicting a temporal sequence similar to that they showed in the ordinations obtained by analysing the water bodies one by one. Conversely, the coda did not show any successional trend but they were clearly separated and formed groups which identified the single water body. This result suggests that local conditions and the local pool of available species have thus a strong effect, which can be considered as important as that exerted by 
seasonal/climatic constraints. To explain this result, concepts deriving from the game theory can be used. In mathematics, game theory models strategic situations, or games, in which an individual's success in making choices depends on the choices of others (Myerson, 1997). In this context, we can consider individual organisms as the players, the functional group which collects them as their strategies, and their relative biomass values (largely depending on their net growth rates or fitness) as their payoffs (see McGill \& Brown, 2007). The game happens because the fitness of an individual is simultaneously influenced by its own strategy and by the strategies of others. A change in the composition of "others" imposes a different strategy to all players. In this view, the rare species and the different annual colonizers, which may be regarded as occasional players, have the possibility to influence the strategies of the 'regular' players making each ecosystem unique and different from the others. In this way, rare species, as also shown by Padisák et al. (2010), assume a structuring effect on the dominant phytoplankton species, and besides constituting the ecological memory of aquatic ecosystems (Padisák, 1992), they can actively influence the dynamics of dominant phytoplankton groups.

In conclusion, the functional classification of phytoplankton allows to represents the ecological phases, which characterizes the seasonal succession of phytoplankton in macrophyte-dominated Mediterranean ponds. In particular, the specific and the recurrent sequence of coda, as resulted in the present study, seem to confirm the hypothesis of a regional coherence in the development of phytoplankton in Mediterranean ponds. However, the temporary character of a pond may allow for the possibility of a resetting phase, which enables these environments to counteract a large number of environmental impacts including the variability of the meteorological elements (temperature, duration and occurrence of precipitation) typical of Mediterranean climate. However, deep alteration of these climatic features as predicted by climate change models may enhance water overexploitation and severely endanger these ecosystems. The resetting phase eventually favours the possibility for new colonizers to develop, and potentially increases local biodiversity. This allows the existence of a large pool of rare species. The species richness is further increased by the coexistence of metaphytic, planktic and benthic species which constitute the element of compositional dissimilarity and dynamical singularity that makes each pond different and contributes to increase regional biodiversity.

\section{References}

Amalfitano, S., S. Fazi, A. Zoppini, A. Barra Caracciolo, P. Grenni \& A. Puddu, 2008. Responses of benthic bacteria to experimental drying in sediments from Mediterranean temporary rivers. Microbial Ecology 55: 270-279.

Barone, R., G. Castelli \& L. Naselli-Flores, 2010. Red sky at night Cyanobacteria delight: the role of climate in structuring phytoplankton assemblage in a shallow, Mediterranean lake (Biviere di Gela, southeastern Sicily). Hydrobiologia 639: 43-53.

Battle, J. M. \& T. B. Mihuc, 2000. Decomposition dynamics of aquatic macrophytes in the lower Atchafalaya, a large floodplain river. Hydrobiologia 418: 123-136.

Borics, G., B. Tóthmérész, I. Grigorszky, J. Padisák, G. Várbíró \& S. Szabó, 2003. Algal assemblage types of boglakes in Hungary and their relation to water chemistry, hydrological conditions and habitat diversity. Hydrobiologia 502: $145-155$.

Cancela da Fonseca, L., M. Cristo, M. Machado, J. Sala, J. Reis, R. Alcazar \& P. Beja, 2008. Mediterranean temporary ponds in Southern Portugal: key faunal groups as management tools? Pan-American Journal of Aquatic Sciences 3: 304-320.

Céréghino, R., J. Biggs, B. Oertli \& S. Declerck, 2008. The ecology of European ponds: defining the characteristics of a neglected freshwater habitat. Hydrobiologia 597: 1-6.

Chrisostomou, A., M. Moustaka-Gouni, S. Sgardelis \& T. Lanaras, 2009. Air-dispersed phytoplankton in a Mediterranean river-reservoir system (Aliakmon-Polyphytos, Greece). Journal of Plankton Research 31: 877-884.

Cunha Pereira, H., N. Allott \& C. Coxon, 2010. Are seasonal lakes as productive as permanent lakes? A case study from Ireland. Canadian Journal of Fisheries and Aquatic Sciences 67: 1291-1302.

De Meester, L., S. Declerck, R. Stoks, G. Louette, F. van De Meutter, T. De Bie, E. Michels \& L. Brendonck, 2005. Ponds and pools as model systems in conservation biology, ecology and evolutionary biology. Aquatic Conservation: Marine and Freshwater Ecosystems 15: 715-725.

Dimitriou, E., E. Moussoulis, F. Stamati \& N. Nikolaidis, 2009. Modelling hydrological characteristics of Mediterranean temporary ponds and potential impacts from climate change. Hydrobiologia 634: 195-208.

Fazi, S., S. Amalfitano, C. Piccini, A. Zoppini, A. Puddu \& J. Pernthaler, 2008. Colonization of overlaying water by bacteria from dry river sediments. Environmental Microbiology 10: 2760-2772.

Foissner, W., 2006. Biogeography and dispersal of microorganisms: a review emphasizing protists. Acta Protozoologica 45: 111-136.

Genitsaris, S., M. Moustaka-Gouni \& K. A. Kormas, 2011. Airborne microeukaryote colonists in experimental water containers: diversity, succession, life histories and established food webs. Aquatic Microbial Ecology 62: 139-152. 
Grillas, P., L. Rhazi \& M. Rhazi, 2009. The vegetation of temporary pools: adaptation and opportunism. In: Fraga I Arguimbau P. (ed.). International Conference on Mediterranean Temporary Ponds. Consell Insular de Menorca. Recerca 14. Maó: 111-129.

Gross, E., S. Hilt, P. Lombardo \& G. Mulderij, 2007. Searching for allelopathic effects of submerged macrophytes on phytoplankton - state of the art and open questions. Hydrobiologia 584: 77-88.

Hammer, O., D. A. T. Harper \& P. D. Ryan, 2001. Past: paleontological statistics software package for education and data analysis. Palaeontologia Electronica 4: 4-9.

Hillebrand, H., C. D. Dürselen, D. Kirschtel, U. Pollingher \& T. Zohary, 1999. Biovolume calculation for pelagic and benthic microalgae. Journal of Phycology 35: 403-424.

Krasznai, E., G. Borics, G. Várbíró, A. Abonyi, J. Padisák, C. Deák \& B. Tóthmérész, 2010. Characteristics of the pelagic phytoplankton in shallow oxbows. Hydrobiologia 639: 173-184.

Kruskal, J. B. \& M. Wish, 1978. Multidimensional Scaling. Sage Publications, London: 96 pp.

Marrone, F. \& L. Naselli-Flores, 2011. Primo reperto di una lenticchia d'acqua alloctona in Sicilia: Lemna minuta Kunth (Araceae, Lemnoideae). Il Naturalista Siciliano 35: 179-185.

Marrone, F., R. Barone \& L. Naselli-Flores, 2006. Ecological characterization and cladocerans, calanoid copepods and large branchiopods of temporary ponds in a Mediterranean island (Sicily, southern Italy). Chemistry and Ecology 22(Suppl. 1): 181-190.

McGill, B. J. \& J. S. Brown, 2007. Evolutionary game theory and adaptive dynamics of continuous traits. Annual Review of Ecology Evolution and Systematics 38: 403-435.

Moyá, G. \& V. Conforti, 2009. Cyanobacteria and microalgae communities in temporary ponds. In: Fraga i Arguimbau, P. (ed.). International Conference on Mediterranean Temporary Ponds. Proceedings \& Abstracts. Consell Insular de Menorca. Recerca, 14. Maó, Menorca: 95-106.

Mozley, A., 1944. Temporary ponds, neglected natural resource. Nature 154: 490.

Myerson, R. B., 1997. Game Theory: Analysis of Conflict. Harvard University Press, Cambridge: 600 pp.

Naselli-Flores, L., 2003. Man-made lakes in Mediterranean semi-arid climate: the strange case of Dr Deep Lake and $\mathrm{Mr}$ Shallow Lake. Hydrobiologia 506-509: 13-21.

Naselli-Flores, L. \& R. Barone, 1994. Relationship between trophic state and plankton community structure in 21 Sicilian dam reservoirs. Hydrobiologia 275(276): 197-205.

Naselli-Flores, L. \& R. Barone, 2002. Limnology of a small, temporary pond: the Pond of Santa Rosalia (Sicily, Italy). Verhandlungen des Internationalen Verein Limnologie 28: 1673-1677.

Naselli-Flores, L. \& R. Barone, 2005. Water-level fluctuations in Mediterranean reservoirs: setting a dewatering threshold as a management tool to improve water quality. Hydrobiologia 548: 85-99.
Naselli-Flores, L. \& G. Rossetti, 2010. Santa Rosalia, the icon of biodiversity. Hydrobiologia 653: 235-243.

Naselli-Flores, L., R. Barone, I. Chorus \& R. Kurmayer, 2007. Toxic cyanobaterial blooms in reservoirs under a semiarid Mediterranean climate: the magnification of a problem. Environmental Toxicology 22: 399-404.

Oertli, B., J. Biggs, R. Céréghino, P. Grillas, P. Joly \& J.-B.Lachavanne, 2005. Conservation and monitoring of pond biodiversity: introduction. Aquatic Conservation: Marine and Freshwater Ecosystems 15: 535-540.

Oertli, B., R. Céréghino, J. Biggs, S. Declerck, A. Hull \& M. R. Miracle (eds), 2010. Pond Conservation in Europe. Developments in Hydrobiology 210. Springer, Dordrecht: $386 \mathrm{pp}$.

Padisák, J., 1992. Seasonal succession of phytoplankton in a large shallow lake (Balaton, Hungary) - a dynamic approach to ecological memory, its possible role and mechanisms. Journal of Ecology 80: 217-230.

Padisák, J., L. Crossetti \& L. Naselli-Flores, 2009. Use and misuse in the application of the phytoplankton functional classification: a critical review with updates. Hydrobiologia 621: 1-19.

Padisák, J., É. Hajnal, L. Krienitz, J. Lakner \& V. Üveges, 2010. Rarity, ecological memory, rate of floral change in phytoplankton - and the mystery of the red cock. Hydrobiologia 653: 45-64.

Podani, J., 2000. Introduction to the exploration of multivariate biological data. Backhuys, Leiden: $407 \mathrm{pp}$.

Reynolds, C. S., V. L. Huszar, C. Kruk, L. Naselli Flores \& S. Melo, 2002. Towards a functional classification of the freshwater phytoplankton. Journal of Plankton Research 24: 417-428.

Ribeiro Rodrigues, L. H., E. Bertazzo Canterle, V. Becker, V. Gazulha, A. Hamester \& D. da Motta Marques, 2011. Dynamics of plankton and fish in a subtropical temporary wetland: rice fields. Scientific Research and Essays 6: 2069-2077.

Robarts, R. D., M. T. Arts \& D. B. Donald, 1995. Phytoplankton primary production of three temporary northern prairie wetlands. Canadian Journal of Fisheries and Aquatic Sciences 52: 897-902.

Scheffer, M., 1998. Ecology of Shallow Lakes. Chapman \& Hall, London: 357 pp.

Tartari, G. A. \& R. Mosello, 1997. Metodologie analitiche e controlli di qualità nel laboratorio chimico dell'Istituto Italiano di Idrobiologia. Documenta dell'Istituto Italiano di Idrobiologia 60: 1-160.

Van Donk, E. \& W. J. Van de Bund, 2002. Impact of submerged macrophytes including charophytes on phyto- and zooplankton communities: allelopathy vs other mechanisms. Aquatic Botany 72: 261-274.

Wilbur, H. M., 1997. Experimental ecology of food webs: complex systems in temporary ponds. Ecology 78: 2279-2302.

Williams, D. D., 2006. The Biology of temporary waters. Oxford University Press, Oxford: 337 pp. 